'Shall we go through it once again?' Esmé Percy asked. But Shaw was sorry for them and advised them to stop. We all gathered round for a chat.

'I'm also doing Orinthia in your Apple Cart at the Malvern Festival. I'd like to ask you a terribly intimate question.' Frances Day looked into his eyes, and before she had finished the question Shaw was answering: 'It doesn't matter in the least whether King Magnus and Orinthia slept together. I'm pretty certain they didn't, though of course I don't know all their secrets. No good playwright knows all the secrets of his characters. Judging from my own relationship with women, I am prepared to say it was a platonic relationship. Like finger-prints, all love-affairs are different. You must not confuse the sensual with the enduring relationship of man and wife. All Nature wants is to produce babies, but we are human beings and can order our lives differently. Take Saint Joan. Why did she interest me?'

'I've never read Saint Joan. . . . I've seen the film. . . .' Frances Day wondered why her remark brought the biggest laugh of the afternoon.

\title{
Why She Would Not
}

From Mrs Georgina Musters to Archibald Henderson, 31 October 1955; letter quoted in Henderson, George Bernard Shaw: Man of the Century (New York: Appleton-Century-Crofts, 1956) p. 665. Shaw began the writing of Why She Would Not: A Little Comedy in the summer of 1950. Mrs Musters, who had previously made a sixteen-page typescript of the play, visited Shaw in company with Lady Astor on 25 October 1950, a week before his death. At the end of the first draft of Why She Would Not, Shaw had written, 'End of Scene 5 and of the play'; but there is some evidence that he had thought of adding at least one more scene.

We talked about it [the little comedy]. . . . I had typed it for him and nobody but he and I knew of it - and said with great stress 'It's not worth finishing. . . . It's not good enough.' Then he added 'It's all wrong' and went on to say that hitherto he had considered the important part of marriage the children, but (again with great emphasis) 'NO, it's the companionship that matters.' . . . (I then realised what a very lonely seven years he had had since the death of Charlotte in 1943.) 